\title{
Extractable Phosphorus Contents of Some Soils of Bangladesh and Their Correlation with Phosphorus Concentration in Rice Leaves
}

\author{
Enamul Haque, Abul Kashem*, Khan Towhid Osman \\ Department of Soil Science, University of Chittagong, Chittagong, Bangladesh. \\ Email: Kashem00@yahoo.com
}

Received March $28^{\text {th }}, 2013$; revised May $1^{\text {st }}, 2013$; accepted May $10^{\text {th }}, 2013$

Copyright (C) 2013 Enamul Haque et al. This is an open access article distributed under the Creative Commons Attribution License, which permits unrestricted use, distribution, and reproduction in any medium, provided the original work is properly cited.

\begin{abstract}
To observe the availability of phosphorus by different extraction methods in some cultivated soils of Hathazari Upazilla of Chittagong District, this study was carried out with 36 surface soil samples $(0-15 \mathrm{~cm})$ belonging to six soil series, namely Bijipur, Pahartali, Mirsarai, Manu, Raojan and Noapara. Physical and chemical characteristics of the soils were also determined with an objective of identifying the soil factor(s) regulating $\mathrm{P}$ extractability. Three $\mathrm{P}$ extraction methods, namely Olsen $\left(0.5 \mathrm{M} \mathrm{NaHCO}_{3}\right.$, pH 8.5), Mehlich-3 $\left(0.2 \mathrm{~N} \mathrm{CH}_{3} \mathrm{COOH}+0.013 \mathrm{~N} \mathrm{HNO}_{3}+0.015 \mathrm{~N} \mathrm{NH}_{4} \mathrm{~F}+0.25 \mathrm{~N} \mathrm{NH}_{4}\right.$ $\mathrm{NO}_{3}+0.001 \mathrm{M}$ EDTA) and Bray \& Kurtz-1 $\left(0.03 \mathrm{~N} \mathrm{NH}_{4} \mathrm{~F}+0.025 \mathrm{~N} \mathrm{HCl}\right)$ were used. There was a wide variation in the extractability of $\mathrm{P}$ ranging from low to high categories. Olsen method extracted the largest amount of P (2.07 - 45.36 $\left.\mathrm{mg} \cdot \mathrm{kg}^{-1}\right)$ while Bray \& Kurtz-1 extracted the smallest amount $\left(1.02-21.79 \mathrm{mg} \cdot \mathrm{kg}^{-1}\right)$. The mean extractable P in soils was found to be in the order of Olsen $>$ Mehlich-3 $>$ Bray \& Kurtz-1. Soil pH was the most dominant factor in determining P extractability. Available $\mathrm{P}$ was negatively correlated with percentage of clay, organic carbon and CEC and positively correlated with $\mathrm{pH}$. Although the three methods extracted different amounts of $\mathrm{P}$ from soil, values of $\mathrm{P}$ extracted by the different methods were strongly correlated among themselves and with the leaf phosphorus concentration of rice growing in these soils.
\end{abstract}

Keywords: Soil Series; Available P; Olsen P; Mehlich-3 P; Bray \& Kurtz-1 P

\section{Introduction}

Phosphorus is an essential plant nutrient and has important roles in plant physiology including synthesis of carbohydrates, fats and proteins. It performs important roles in energy transformations in plants mainly involving high energy phosphate compounds such ADP, ATP, NADP, etc. [1]. Phosphorus is also involved in numerous enzymatic reactions in plants. Phosphorus contributes to both vegetative and reproductive growth of plants. But the chemistry of phosphorus in soil is extremely complicated undergoing solubilization, insolubilization, sorption and desorption. Soils become often deficient in this critical element. It is considered to be the most unavailable and inaccessible of all mineral nutrients [2]. For good $\mathrm{P}$ soil management, it is important to know available soil $\mathrm{P}$ status.

Conventional soil test methods for available phospho-

*Corresponding author. rus often use distilled water or a variety of other extractants (solutions of acids, bases, salts or a mixture of reagents as well) that may extract forms of $\mathrm{P}$ that can be absorbed by plants. They may also extract some stable and non-labile soil $\mathrm{P}$ which becomes available slowly. Currently, there has become a tendency to encourage the use of mild reactants for the simultaneous extraction of both major elements and micronutrients, in order to perform simple, low-cost, and time saving routine procedures [3]. Among these "multiple-element" or "universal soil" extractants, the most popular is the Mehlich-3 extractant [4]. Nowadays, Mehlich-3 is widely adopted in the USA and Canada. Conversely, most of the soil testing laboratories of European countries are still employ the Olsen reagent [5] as official soil test. Several other P extraction methods using acids, organic and inorganic complexing agents, or alkaline solutions have been developed [6]. The extractants often extract all or part of the labile $\mathrm{P}$, which is considered available to plants dur- 
ing their growth cycle, plus an undefined proportion of other forms of soil P. Because several soil properties influence the extraction of $\mathrm{P}$, it is not surprising that there is no one best extractant at all conditions $[7,8]$. Some extractants may fail to extract plant available $\mathrm{P}$ if they are used on soil types for which they are not appropriate $[9,10]$. Unless a soil test $P$ value is correlated with crop response or plant uptake of $\mathrm{P}$, it is very difficult to judge suitability of an extractant for available $\mathrm{P}$ of a soil or group of soils. In the present study, available P content of soils of 36 rice fields belonging to six soil series were determined by three methods including Bray and Kurtz-1, Mehlich-3 and Olsen methods, and their values were correlated with leaf P concentration of rice growing in farmers field.

\section{Materials and Methods}

\subsection{Collection of Soil Samples}

Six soil series namely Bijipur, Pahartali, Mirsarai, Manu, Raojan and Noapara were selected on the basis of their land types, drainage, textures and parent materials and covering major soils of the Hathazari Upazilla of Chittagong. Multiple soil samples from each soil series were collected for evaluating the P availability status. Characteristics of these soil series have been defined by the Soil Resources Development Institute of Bangladesh [11]. The soils were silty clay to sandy loam and within the same soil order Inceptisols (Table 1).

\subsection{Soil Analysis}

Collected soil samples were air dried, ground and sieved through a $2 \mathrm{~mm}$ sieve. Soil samples were dried in an oven at $105^{\circ} \mathrm{C}$ for 48 hours before analysis. Particle size analysis was made by hydrometer method described by Day [12]. Soil pH was measured by corning (Model-7) glass electrode $\mathrm{pH}$ meter from soil water suspension at the ratio of 1:2.5. Soil organic carbon was determined by Walkley and Black's wet oxidation method [13]. Cation exchange capacity was determined by using $1 \mathrm{~N}$ $\mathrm{NH}_{4} \mathrm{OAC}$ solution at $\mathrm{pH} 7.0$ [14]. Available phosphorus of soil was extracted with three different extractants $[4,5$, 15]. To measure Mehlich-3 [4] and Bray \& Kurtz-1 [15] extractable $\mathrm{P}, 2 \mathrm{~g}$ soil was extracted with $20 \mathrm{ml}$ of Mehlich-3 extractant $\left(0.2 \mathrm{~N} \mathrm{CH}_{3} \mathrm{COOH}+0.013 \mathrm{~N} \mathrm{HNO}_{3}+\right.$ $0.015 \mathrm{~N} \mathrm{NH}_{4} \mathrm{~F}+0.25 \mathrm{~N} \mathrm{NH}_{4} \mathrm{NO}_{3}+0.001 \mathrm{M}$ EDTA) and with $20 \mathrm{ml}$ of Bray \& Kurtz-1 extractant $\left(0.03 \mathrm{~N} \mathrm{NH}_{4} \mathrm{~F}+\right.$ $0.025 \mathrm{~N} \mathrm{HCl}$ ), respectively after 5 minutes shaking at room temperature. In the case of Olsen $\mathrm{P}$ [5], $1 \mathrm{~g}$ soil was extracted with $20 \mathrm{ml}$ of $0.5 \mathrm{M} \mathrm{NaHCO}_{3}, \mathrm{pH} 8.5$ at 30 minutes shaking time. Phosphorus in the soil extracts was determined spectrophotometrically by the ascorbic acid blue color method [16]. Statistical analyses were done by using Minitab program [17].

\subsection{Leaf Analysis}

Mature leaves of rice (Oryza sativa) growing in farmers fields during the time of soil sampling were collected, dried in the laboratory, ground and digested in conc. $\mathrm{H}_{2} \mathrm{SO}_{4}+\mathrm{H}_{2} \mathrm{O}_{2}+\mathrm{LiSO}_{4}$ digestion mixture [18] and analyzed for $\mathrm{N}, \mathrm{P}$ and $\mathrm{K}$. Nitrogen in extract was determined by micro-Kjehdahl distillation, $\mathrm{P}$ by vanadomolybdate yellow colour in spectrophotometer and $\mathrm{K}$ in an atomic absorption spectrophotometer. Soil test $\mathrm{P}$ values were correlated (Pearson's simple linear correlation) with leaf $P$ values.

\section{Results and Discussion}

The mean values for different physical and chemical parameters of soils are presented in Table 2 on soil series basis. There was a wide variation in soil texture among the soil series. For example, percentage of sand ranged from 14 (Raojan series) to 74 (Mirsarai series), silt from

Table 1. A correlation between the soil series and different soil classification systems.

\begin{tabular}{|c|c|c|c|c|c|c|}
\hline Soil series & USDA soil family & Land type & $\begin{array}{l}\text { Drainage } \\
\text { conditions }\end{array}$ & $\begin{array}{l}\text { Deposits } \\
\text { material }\end{array}$ & $\begin{array}{c}\text { Flood } \\
\text { conditions }\end{array}$ & $\begin{array}{l}\text { Subsoil } \\
\text { texture }\end{array}$ \\
\hline Bijipur & Typic endoaquepts & $\begin{array}{l}\text { High land to medium } \\
\text { high land }\end{array}$ & $\begin{array}{l}\text { Imperfect } \\
\text { to poor }\end{array}$ & Recent piedmont & $\begin{array}{l}\text { Intermittently and } \\
\text { seasonally flooded }\end{array}$ & Sandy loam \\
\hline Pahartali & Aeric endoaquepts & $\begin{array}{l}\text { Medium low land } \\
\text { to High land }\end{array}$ & $\begin{array}{l}\text { Imperfect } \\
\text { to poor }\end{array}$ & Piedmont & $\begin{array}{l}\text { Intermittently and } \\
\text { seasonally flooded }\end{array}$ & $\begin{array}{l}\text { Silt loam or } \\
\text { loam }\end{array}$ \\
\hline Mirsarai & Typic endoaquepts & $\begin{array}{l}\text { Medium low land } \\
\text { to High land }\end{array}$ & $\begin{array}{l}\text { Imperfect } \\
\text { to poor }\end{array}$ & Piedmont & $\begin{array}{l}\text { Intermittently and } \\
\text { seasonally flooded }\end{array}$ & $\begin{array}{l}\text { Silty clay loam } \\
\text { or clay loam }\end{array}$ \\
\hline Manu & Aeric dystrudepts & $\begin{array}{l}\text { Medium low land } \\
\text { to High land }\end{array}$ & $\begin{array}{l}\text { Imperfect } \\
\text { to poor }\end{array}$ & Piedmont alluvial plain & $\begin{array}{l}\text { Intermittently and } \\
\text { seasonally flood }\end{array}$ & $\begin{array}{l}\text { Silty clay } \\
\text { or clay }\end{array}$ \\
\hline Raojan & $\begin{array}{l}\text { Aeric endoaquepts; } \\
\text { some are aeric halaquepts }\end{array}$ & $\begin{array}{l}\text { Medium high land } \\
\text { and medium low land }\end{array}$ & $\begin{array}{l}\text { Poorly } \\
\text { drained }\end{array}$ & Recent tidal deposits & $\begin{array}{l}\text { Intermittently and } \\
\text { seasonally flood }\end{array}$ & Silty clay loam \\
\hline Noapara & Typic endoaquepts & $\begin{array}{l}\text { Medium high land } \\
\text { and medium low land }\end{array}$ & $\begin{array}{l}\text { Poorly } \\
\text { drained }\end{array}$ & Recent tidal sediment & Seasonally flood & Silty clay \\
\hline
\end{tabular}


Table 2. General properties of soils.

\begin{tabular}{ccccccccccc}
\hline Soil series & Sand (\%) & Silt (\%) & Clay (\%) & Textural class & $\mathbf{p H}$ & Org. C (\%) & Total N (\%) & C/N & CEC cmol·kg $\mathbf{~}^{-1}$ \\
\hline Bijipur & 56 & 29 & 15 & Sandy loam & 5.4 & 1.10 & 0.12 & 9 & 9.77 \\
Pahartali & 45 & 35 & 20 & Loam & 6.5 & 0.83 & 0.08 & 10 & 11.81 \\
Mirsarai & 48 & 30 & 22 & Loam & 5.4 & 1.54 & 0.14 & 11 & 8.74 \\
Manu & 36 & 40 & 24 & Loam & 6.2 & 0.75 & 0.07 & 11 & 17.21 \\
Raojan & 16 & 46 & 38 & Silty clay loam & 5.6 & 1.03 & 0.09 & 11 & 15.68 \\
Noapara & 33 & 41 & 26 & Loam & 5.5 & 0.95 & 0.09 & 11 & 14.12 \\
\hline
\end{tabular}

11(Mirsarai series) to 55 (Raojan series) and clay varied from 12 (Bijipur series) to 41 (Raojan series). There was also considerable variation in soil texture within a soil series. However, soils were generally sandy loam in texture in Bijipur series, loam in Pahartali, Mirsari, Manu and Noapara series, silty clay loam in Raojan series. Thus, loam was by far the dominant soil texture.

Soil $\mathrm{pH}$ varied from 5.0 to 6.9. In Bijipur, Phartali, Mirsarai, Manu, Raojan and Noapara series, the mean $\mathrm{pH}$ values were $5.4,6.5,5.4,6.2,5.6$ and 5.5 , respectively. Thus the soils are moderately acid [19]. Organic carbon content ranged from $0.27 \%$ to $1.94 \%$. The mean values of organic carbon of six soil series were $1.10 \%, 0.83 \%$, $1.54 \%, 0.75 \%, 1.03 \%$ and $0.95 \%$ in Bijipur, Phartali, Mirsarai, Manu, Raojan and Noapara series, respectively. The soils are, therefore, poor in organic matter contents as most other soils of Bangladesh. According to BARC [19], most Bangladesh soils have less than $1.5 \%$ organic matter $($ organic matter $=$ organic carbon $\times 1.724)$. Cation exchange capacity ranged from 5.7 to $21.0 \mathrm{cmol} \cdot \mathrm{kg}^{-1}$ with the ranges of $7.88-12.90,8.85-14.87,5.67-11.90$, 12.62 - 20.96, $14.24-17.58$ and $12.21-15.63 \mathrm{cmol} \cdot \mathrm{kg}^{-1}$ in Bijipur, Pahartali, Mirsarai, Manu, Raojan and Noapara series, respectively. Therefore, there was considerable variation in CEC within some soil series. The mean values of the corresponding soil series were 9.77, 11.81, $8.74,17.21,15.68$ and $14.12 \mathrm{cmol} \cdot \mathrm{kg}^{-1}$. Mean total nitrogen content of the soil series varied between 0.07 to 0.14 percent, so that the $\mathrm{C} / \mathrm{N}$ ratio became 9 to 11 . Table 3 presents the F-values (variance ratio) of different soil parameters and their sources of variation. Soil properties included \% clay, pH, Org.C and CEC. From the physical and chemical properties, the presently studied soils appear to be poorly fertile.

The mean values of $\mathrm{P}$ extracted by different methods from 36 soil samples of 6 soil series are presented in Table 4 . There was a wide variation amongst the soils in extractable P.

\subsection{Olsen $P$}

There was an overall variation of in 2.07 to 45.36
Table 3. Analysis of variance for different soil properties.

\begin{tabular}{ccc}
\hline Parameters & Sources of variation & F-value \\
\hline \% Clay & Series & $14.81^{* *}$ \\
pH & Series & $12.80^{* *}$ \\
Org. C & Series & $5.03^{*}$ \\
CEC & Series & $13.73^{* *}$ \\
Olsen P & Series & $75.07^{* *}$ \\
Mehlich-3 P & Series & $114.70^{* *}$ \\
Bray \& Kurtz-1 P & Series & $50.87^{* *}$ \\
Available P & Methods & $6.51^{*}$ \\
\hline
\end{tabular}

${ }^{* *}$ Significant at $\mathrm{p}<0.001 ;$ ' Significant at $\mathrm{p}<0.01$.

$\mathrm{mg} \cdot \mathrm{kg}^{-1}$ Olsen $\mathrm{P}$ in the soils samples. The mean Olsen $\mathrm{P}$ values of six soil series were 25.80, 35.14, 4.66, 13.26, 5.44 and $3.10 \mathrm{mg} \mathrm{kg}^{-1}$ in Bijipur, Pahartali, Mirsarai, Manu, Raojan and Noapara series, respectively (Table 4). The average Olsen $P$ was $14.57 \mathrm{mg} \cdot \mathrm{kg}^{-1}$. Tukey's test for multiple means comparison showed that the means of Olsen P of Pahartali and Bijipur, Bijipur and Manu and Pahartali and Manu are significantly different at $p=0.05$ level. There was also significant difference in mean Olsen P for Pahartali at $p=0.05$ level from with Mirsarai, Raojan and Noapara series. But no significant difference was observed among Mirsarai, Raojan and Noapara series. On response by different crops, Bingham [20] established values for Olsen $\mathrm{P}$ as follows: $<5 \mathrm{mg} \cdot \mathrm{kg}^{-1}$ low; 6 to $10 \mathrm{mg} \cdot \mathrm{kg}^{-1}$ moderate and $>11 \mathrm{mg} \cdot \mathrm{kg}^{-1}$ high. Based on this classification, the presently studied Noapara and Mirsari series fall in low, Raojan medium and Bijipur, Pahartali and Manu series fall in the high category. In loam to clay soils for upland crops, SRDI [21] classified soils on the basis of Olsen $\mathrm{P}$ as follows: $<7.5 \mathrm{mg} \cdot \mathrm{kg}^{-1}$ very low; $7.51-15.0 \mathrm{mg} \cdot \mathrm{kg}^{-1}$ low; $15.1-22.5 \mathrm{mg} \cdot \mathrm{kg}^{-1}$ medium; $22.51-30 \mathrm{mg} \cdot \mathrm{kg}^{-1}$ optimum; $30.1-37.5$ $\mathrm{mg} \cdot \mathrm{kg}^{-1}$ high and $>37.5 \mathrm{mg} \cdot \mathrm{kg}^{-1}$ very high. Based on this classification, the presently studied Mirsarai, Raojan and Noapara series fall in very low, Manu low, Bijipur opti- 
Table 4. Available phosphorus contents $\left(\mathrm{mg} \cdot \mathrm{kg}^{-1}\right)$ in soils different series determined by three different methods.

\begin{tabular}{cccc}
\hline Series name & Olsen & Mehlich-3 & Bray \& Kurtz $-\mathbf{1}$ \\
\hline Bijipur & $25.80^{\mathrm{b}} \pm 3.64$ & $21.14^{\mathrm{a}} \pm 3.38$ & $15.17^{\mathrm{a}} \pm 4.54$ \\
Pahartali & $35.14^{\mathrm{a}} \pm 7.51$ & $20.69^{\mathrm{a}} \pm 3.09$ & $15.30^{\mathrm{a}} \pm 2.96$ \\
Mirsarai & $4.66^{\mathrm{d}} \pm 1.06$ & $3.54^{\mathrm{b}} \pm 1.39$ & $1.95^{\mathrm{b}} \pm 0.73$ \\
Manu & $13.26^{\mathrm{c}} \pm 2.71$ & $4.15^{\mathrm{b}} \pm 1.53$ & $3.30^{\mathrm{b}} \pm 1.44$ \\
Raojan & $5.44^{\mathrm{d}} \pm 1.80$ & $2.53^{\mathrm{b}} \pm 0.82$ & $1.69^{\mathrm{b}} \pm 0.27$ \\
Noapara & $3.10^{\mathrm{d}} \pm 1.20$ & $2.42^{\mathrm{b}} \pm 0.78$ & $1.76^{\mathrm{b}} \pm 0.55$ \\
\hline
\end{tabular}

Means followed by the same letter(s) in column are not significantly different at $\mathrm{p}<0.05 . \pm$ indicates standard deviation.

mum and Pahartali series fall in high range of available $\mathrm{P}$.

\subsection{Mehlich-3 P}

Mehlich-3 P of the soils varied from 1.61 to $24.86 \mathrm{mg}$ $\mathrm{kg}^{-1}$ among the individual soil samples. The mean extractable $\mathrm{P}$ concentration determined by the Mehlich-3 method ranged from 2.42 (Noapara) to 21.14 (Bijipur) $\mathrm{mg} \mathrm{kg}{ }^{-1}$ with an average value of $9.08 \mathrm{mg} \cdot \mathrm{kg}^{-1}$ for the six soil series. The mean values of other four soil series were 20.69 for Pahartali, 3.54 Mirsarai, 4.15 Manu, and 2.53 Raojan (Table 4). Tukey's test for multiple means comparison showed that the means of Mehlich-3 P for Bijipur and Pahartali series with Mirsarai, Manu, Raojan and Noapara series are significantly different at $p=0.05$ level, while no significant difference was observed in the means of Bijipur and Pahartali series. There also no significant difference was observed among Mirsarai, Manu, Raojan and Noapara series. The critical level of Mehlich-3 extractable $P$ for most common crops was about 50 to $60 \mathrm{mg} \cdot \mathrm{kg}^{-1}[22,23]$. But Mehlich-3 P of the presently studied soil series falls below this critical level.

\subsection{Bray \& Kurtz-1 $P$}

The Bray \& Kurtz-1 extractable $\mathrm{P}$ had an overall range from 1.02 to $21.79 \mathrm{mg} \cdot \mathrm{kg}^{-1}$. The mean values of six soil series were 15.17, 15.30, 1.95, 3.30, 1.69 and 1.76 $\mathrm{mg} \cdot \mathrm{kg}^{-1}$ in Bijipur, Pahartali, Mirsarai, Manu, Raojan and Noapara series, respectively (Table 4) with an average value of $6.53 \mathrm{mg} \cdot \mathrm{kg}^{-1}$. Tukey's test for multiple means comparison showed that the means of Bray \& Kurtz-1 P for Bijipur and Pahartali series with Mirsarai, Manu, Raojan and Noapara series are significantly different at $p=0.05$ level, while no significant difference was observed in the means of Bijipur and pahartali series. There also no significant difference was observed among Mirsarai, Manu, Raojan and Noapara series.

On response by different crops to Bray \& Kurtz-1 P, Bingham [20] classified soils as follows: $<7 \mathrm{mg} \cdot \mathrm{kg}^{-1}$ deficient; 7 to $20 \mathrm{mg} \cdot \mathrm{kg}^{-1}$ probable response and $>20$ $\mathrm{mg} \cdot \mathrm{kg}^{-1}$ high or unlikely response. Based on this classification, the presently studied Mirsarai, Manu, Raojan and Noapara series can be classified as deficient in available P; Bijipur and Pahartali series fall in the probable response class in P-status. SRDI [21] classified available Bray \& Kurtz-1 P in loam to clay soils for upland crops as follows: $<5.25 \mathrm{mg} \cdot \mathrm{kg}^{-1}$ very low; 5.251 $10.5 \mathrm{mg} \cdot \mathrm{kg}^{-1}$ low; $10.51-15.75 \mathrm{mg} \cdot \mathrm{kg}^{-1}$ medium; 15.76 $21.0 \mathrm{mg} \cdot \mathrm{kg}^{-1}$ optimum; $21.1-26.25 \mathrm{mg} \cdot \mathrm{kg}^{-1}$ high and $>$ $26.25 \mathrm{mg} \cdot \mathrm{kg}^{-1}$ very high. Based on this classification, Mirsarai, Manu, Raojan and Noapara series belong to very low, Bijipur and Pahartali belongs to medium range in available $P$.

\subsection{Comparison of the P Extracting Ability of Different Extractants}

A paired t-test was performed to compare the mean differences of P removed by different extractants. Tukey's test for multiple means comparison showed that the means of Olsen P and Mehlich-3 P; Olsen P and Bray \& Kurtz-1 $\mathrm{P}$ and Mehlich-3 $\mathrm{P}$ and Bray \& Kurtz-1 $\mathrm{P}$ are significantly different at $p=0.05$ level .

The amount of extractable $\mathrm{P}$ varied markedly depending on the soils and extractants used. The maximum amount of P (3.10 - 35.14 $\left.\mathrm{mg} \cdot \mathrm{kg}^{-1}\right)$ was extracted by Olsen method and the minimum $\left(1.69-15.30 \mathrm{mg} \cdot \mathrm{kg}^{-1}\right)$ by Bray \& Kurtz-1 method. As per as individual soils are concerned, the highest extractable $\mathrm{P}$ was obtained from Pahartali series and the lowest from Noapara series. The mean values of $\mathrm{P}$ extracted by different extractants ranked in the order Olsen $>$ Mehlich-3 $>$ Bray \& Kurtz-1 P.

The differences among the $\mathrm{P}$ extraction methods probably arose from the fact that plant available $\mathrm{P}$ in the soil is not from a discrete fraction but from a continuum of fractions; extracting agents preferentially extract from different fractions depending on their reaction with soil components involved in P sorption [24]. In addition, each extracting solution has a different ability to extract varying portions of soil $\mathrm{P}$ because they were targeted at different pools of soil P [25]. The Olsen method extracted statistically higher P than Mehlich-3 and Bray \& Kurtz-1 method. This methods was developed by Olsen et al. [5] 
for calcareous soils, but is now also used in acidic soils as Fardeau et al. [26] described it as the best methods of estimating the available phosphate, not only for calcareous soils but also for acid soils.

Olsen method is the most commonly used in UK and Pakistan. It is very satisfactory on soil with $\mathrm{pH} 6$ or above, but less satisfactory on acidic soils [27]. According to Olsen et al. [5] there are two major mechanisms in $\mathrm{NaHCO}_{3}$ extraction process: 1) increase in calcium phosphate solubility by $\mathrm{NaHCO}_{3}$ as a result of repression of $\mathrm{Ca}^{2+}$ activity, (common ion effect of $\mathrm{Ca}^{2+}$ ions in the presence of solid phase $\mathrm{CaCO}_{3}$ ) and 2) that $\mathrm{HCO}_{3}{ }^{-}$, $\mathrm{CO}_{3}^{2-}$ and $\mathrm{OH}^{-}$ions replace phosphate ions on the surface of soil particles. They further explained that the main effect of $\mathrm{NaHCO}_{3}$ in calcareous soils is to decrease the $\mathrm{Ca}$ activity which in turn increases the solubility of $\mathrm{P}$. In acid and neutral soils the main effect is the ionic competition of $\mathrm{HCO}_{3}^{-}, \mathrm{CO}_{3}^{2-}$ and $\mathrm{OH}^{-}$ions. Chang and Juo [28] and Pratt and Garber [29] had found Olsen's method to be satisfactory for acidic soils. Generally, the Olsen method has been recommended for alkaline calcareous soils, however, in acid soils, sodium bicarbonate $\left(\mathrm{NaHCO}_{3}\right)$ at $\mathrm{pH} 8.5$ extracts the available $\mathrm{P}$ present in the form of Al-P or Fe-P or adsorbed on clay surfaces [30]. This could be the reason of its suitability for these soils. According to Anam et al. [31], $\mathrm{NaHCO}_{3}$ appeared to be the best method for some soils in Bangladesh in extracting available P. Olsen method was mostly used in different experiments in our country [32-34].

In the present study, the quantity of $\mathrm{P}$ extracted by Mehlich-3 extractant was relatively smaller than that removed by Olsen's reagent. Sims [35] reported that the value of Mehlich-3 $\mathrm{P}$ generally set for optimum crop growth and yield (45-50 mg P. $\mathrm{kg}^{-1}$ ) is higher than the critical values used for other standard methods such as Olsen P. The critical value set for Olsen $\mathrm{P}$ was 10 $\mathrm{mg} \cdot \mathrm{P} \cdot \mathrm{kg}^{-1}[36]$. But the results of the present study are not in good agreement with the findings of Sims [35]. Mehlich-3 extractant is a combination of acids, salts, and a chelating agent and is appropriate for extracting $\mathrm{P}$ and other elements from a wide range of soils, from acid to calcareous soils [4]. On most non calcareous soils, the amount of Mehlich-3 extractable $\mathrm{P}$ is approximately the same as that determined by the Bray \& Kurtz-1 method
[37].

The minimum amounts of $\mathrm{P}$ were extracted by Bray \& Kurtz-1 method from all soil series than other methods used in the present study. The Bray \& Kurtz-1 extractant $\left(0.03 \mathrm{~N} \mathrm{NH}_{4} \mathrm{~F}+0.025 \mathrm{~N} \mathrm{HCl}\right)$ extracts mineral phosphates of $\mathrm{Al}$ and to a lesser extent that of $\mathrm{Fe}$ [38]. It is suitable for a wide range of soils, than excluding calcareous soils $[39,40]$. Fluoride forms strong complexes with aluminium $\left(\mathrm{Al}^{3+}\right)$ ions, thus releasing $\mathrm{P}$ from $\mathrm{Al}-\mathrm{P}$ [40].

\subsection{Correlation of Extractable $P$ among Methods and with Soil Properties}

Correlation coefficients among the methods studied for all the soils are presented in Table 5. Correlation analysis revealed that the amounts of P solubilized by extractants were significantly and positively correlated with each other. The best correlation $(\mathrm{r}=0.976, p=0.000)$ was found between Mehlich-3 P and Bray \& Kurtz -1 P followed by Bray \& Kurtz-1 P and Olsen P $(\mathrm{r}=0.927, p$ $=0.000)$ and Olsen $\mathrm{P}$ and Mehlich-3 P $(\mathrm{r}=0.924, p=$ 0.000 ). This result indicates that although the ability of $P$ extraction was different for different extractants, their trends of $\mathrm{P}$ displacement from soil into solution were similar. This is in agreement with the findings of Rahman et al. [34] and Rahman et al. [41].

Correlation between extractable $\mathrm{P}$ and soil properties $(\mathrm{pH}$, organic carbon, clay and $\mathrm{CEC})$ were examined with a view to identifying the soil factors involved in the regulation of $\mathrm{P}$ extraction (Table 5). Influence of soil $\mathrm{pH}$ was the most dominant factor in $\mathrm{P}$ extraction. The extractable $\mathrm{P}$ values for all the soils were positively correlated with soil $\mathrm{pH}$ but Olsen and Bray \& Kurtz-1 methods had significant correlation. The amount of P extracted by different extractants showed significant positive correlations with $\mathrm{pH}$ suggesting that the $\mathrm{pH}$ effect is attributable to reversible adsorption of $\mathrm{P}$ by clays with increasing $\mathrm{pH}$ up to neutrality and release of $\mathrm{P}$ from $\mathrm{Fe}$ or Al oxyhydroxides.

A significant negative correlation was observed between extractable $\mathrm{P}$ with clay contents in all soils. The $\mathrm{P}$ extracted by three methods were negatively correlated with CEC but Mehlich-3 P and Bray \& Kurtz-1 P have

Table 5. Correlation co-efficients between available $P$ and soil properties.

\begin{tabular}{cccccc}
\hline Available P & Clay (\%) & pH & OC (\%) & CEC & Olsen P \\
\hline Olsen P & $-0.553^{* *}$ & $0.566^{* *}$ & $-0.242^{\mathrm{ns}}$ & $-0.196^{\mathrm{ns}}$ \\
Mehlich-3 P & $-0.611^{* *}$ & $0.286^{\mathrm{ns}}$ & $-0.081^{\mathrm{ns}}$ & $-0.383^{*}$ & $0.924^{* *}$ \\
Bray \& Kurtz-1 P & $-0.591^{* *}$ & $0.343^{*}$ & $-0.153^{\mathrm{ns}}$ & $-0.341^{*}$ & $0.927^{* *}$ \\
\hline
\end{tabular}

\footnotetext{
${ }^{* *}$ Significant at $\mathrm{p}<0.001 ;{ }^{*}$ Significant at $\mathrm{p}<0.05 ;{ }^{\mathrm{ns}}$ Not significant.
} 
Table 6. $\mathrm{N}, \mathrm{P}$ and $\mathrm{K}$ concentration $(\%)$ in rice leaves.

\begin{tabular}{cccc}
\hline Series name & $\mathbf{N}$ & $\mathbf{P}$ & $\mathbf{K}$ \\
\hline Bijipur & $2.1 \pm 0.12$ & $0.20 \pm 0.02$ & $1.2 \pm 0.08$ \\
Pahartali & $2.4 \pm 0.10$ & $0.22 \pm 0.01$ & $1.4 \pm 0.14$ \\
Mirsarai & $2.3 \pm 0.14$ & $0.10 \pm 0.02$ & $1.2 \pm 0.12$ \\
Manu & $2.0 \pm 0.08$ & $0.16 \pm 0.03$ & $1.5 \pm 0.09$ \\
Raojan & $2.3 \pm 0.14$ & $0.12 \pm 0.02$ & $1.3 \pm 0.15$ \\
Noapara & $2.5 \pm 0.16$ & $0.14 \pm 0.01$ & $1.1 \pm 0.07$ \\
\hline
\end{tabular}

\pm indicates standard deviation of mean.

Table 7. Correlation coefficients between soil $P$ and leaf $P$.

\begin{tabular}{ccc}
\hline $\begin{array}{c}\text { Independent } \\
\text { variable }\end{array}$ & $\begin{array}{c}\text { Dependent } \\
\text { variable }\end{array}$ & $\begin{array}{c}\text { Correlation } \\
\text { coefficients }\end{array}$ \\
\hline Bray and Kurtz-1 P & Leaf P & $0.915^{*}$ \\
Melich-3 P & Leaf P & $0.895^{*}$ \\
Olsen P & Leaf P & $0.943^{*}$ \\
\hline
\end{tabular}

*Significant at $<0.001$ percent level.

significant relationship. All the extractable $\mathrm{P}$ was negatively correlated with soil organic carbon content but there was no significant relationship among them. The results suggest that irreversible fixation of extractable $\mathrm{P}$ by organic matter occurs and indicate the stability of phosphorus-organic matter complexation.

\subsection{Correlation between Leaf $P$ and Available Soil P}

Phosphorus concentration in growing rice leaves ranged from 0.10 (Mirsarai series) to 0.22 (Pahartali series) percent (Table 6). Leaf $\mathrm{P}$ values were positively and significantly correlated at $<0.01$ percent levels with available $\mathrm{P}$ values of soil obtained with all the three extractants, namely Olsen, Bray and Kurtz-1 and Mehlich-3 (Table 7). Significant correlation coefficients were also observed when the logarithms of soil test values by all these methods were correlated with P uptake [42]. Ngoc and Phung [43] observed significant and positive correlation between soil $\mathrm{P}$ availability indices and plant $\mathrm{P}$ uptake in four cropping periods.

\section{Conclusion}

Extractable $\mathrm{P}$ in the present study varied considerably with the kind of extractants and the type of soils. Among the three extractants used (Olsen, Mehlich-3 and Bray \& Kurtz-1), Olsen extractant, i.e. $0.5 \mathrm{M}$ sodium bicarbonate extracted greatest amount of available $\mathrm{P}$ and Bray \& Kurtz-1 extractant, i.e. $0.03 \mathrm{~N}$ ammonium fluoride and
$0.025 \mathrm{~N}$ hydrochloric acid extracted the least. As phosphorus values extracted by the three methods were highly correlated among themselves and with the leaf phosphorus values, it may be concluded that any of the methods used in the present study is suitable for testing soil P.

\section{REFERENCES}

[1] G. Soepardi, "Sifat Dan Cirri Tanah," Jurusan Tanah. Fakultas Pertanian, IPB, Bogor, 1983.

[2] J. C. R. Holford, "Soil Phosphorus: Its Measurement, and Its Uptake by Plants," Soil Research, Vol. 35, No. 2, 1997, pp. 227-239. doi:10.1071/S96047

[3] G. Diana, A. Figliolia, R. Indiati and I. Perucchini, "Comparison of Conventional and Innovative Soil Phosphorus Tests in Estimating Plant-Available Phosphorus," In: P. Zdruli, P. Steduto and S. Kapur, Eds., 7. International meeting on Soils with Mediterranean Type of Climate (Selected Papers), CIHEAM, Bari, 2002.

[4] A. Mehlich, "Mehlich 3 Soil Test Extractant: A Modification of Mehlich 2 Extractant," Communications in Soil Science and Plant Analysis, Vol. 15, No. 12, 1984, pp. 1409-1416. doi:10.1080/00103628409367568

[5] S. R. Olsen, C. V. Cole, F. S. Watanabe and L. A. Dean, "Estimation of Available Phosphorus in Soils by Extraction with Sodium Bicarbonate," USDA Circular 939, US Govt. Printing Office, Washington DC, 1954.

[6] P. E. Fixen and J. H. Grove, "Testing Soils for Phosphorus," In: R. L. Westerman, Ed., Soil Testing and Plant Analysis, 3rd Edition, Madison, 1990, pp. 141-180.

[7] R. L. Fox, "Predicting Plant Nutrient Requirements-A Rational Approach," Proceedings of the International Symposium Nutrient Management for Sustained Productivity, Department of Soils, Punjab Agricultural University, Ludhiana, 1992, pp. 43-54.

[8] G. W. Thomas and D. E. Peaslee, "Testing Soils for Phosphorus," In: L. M. Walsh and J. D. Beaton, Eds., Soil Testing and Plant Analysis, Soil Science Society of America, Inc. Madison, 1973.

[9] R. G. Menon, S. H. Chien and L. L. Hammond, "Development and Evaluation of the Pi Soil Test for Plant Available Phosphorus," Communication in Soil Science and Plant Analysis, Vol. 21, No. 13-16, 1989, pp. 1131-1150. doi:10.1080/00103629009368295

[10] A. N. Sharpley, "Soil Phosphorus Extracted by Iron-Aluminum-Oxide Impregnated Filter Paper," Soil Science Society of American Journal, Vol. 55, No. 4, 1991, pp. 1038-1041. doi:10.2136/sssaj1991.03615995005500040025x

[11] SRDI, "Reconnaissance Soil Survey," Sadar North Subdivision Chittagong District 1971-1972, Department of Soil Survey, Ministry of Agriculture, Bangladesh, 1976.

[12] P. R. Day, "Particle Fraction and Particle Size Analysis," In: C. A. Black, Ed., Methods of Soil Analysis, ASA, Madison, 1965, pp. 545-567.

[13] A. Walkley and I. A. Black, "An Examination of Degtja- 
reff Method for Determining Soil Organic Matter and a Proposed Modification of the Chromic Acid Titration Method," Soil Science, Vol. 37, No. 1, 1934, pp. 29-37. doi:10.1097/00010694-193401000-00003

[14] M. L. Jackson, "Soil Chemical Analysis," Prentice-Hall Inc., Engiewood Cliffs, New Jersey, 1973.

[15] R. H. Bray and L. T. Kurtz, "Determination of Total, Organic and Available Forms of Phosphorus in Soils," Soil Science, Vol. 59, No. 1, 1945, pp. 39-45. doi:10.1097/00010694-194501000-00006

[16] J. Murphy and J. P. Riley, "A Modified Single Solution Methods for the Determination of Phosphate in Natural Water," Analytica Chimica Acta, Vol. 27, 1962, pp. 31-36. doi:10.1016/S0003-2670(00)88444-5

[17] Minitab Inc., “Minitab User's Guide, Release 11," Minitab, State College, Pennsylvania, 1996.

[18] E. Allen, H. M. Grimshaw, J. A. Parkinson, C. Quamby and J. D. Roberts, "Chemical Analysis," In: P. D. Moore and S. B. Chapman, Eds., Methods in Plant Ecology, Blackwell Scientific, London, 1986, pp. 285-344.

[19] BARC, "Fertilizer Recommendation Guide," The Bangladesh Agricultural Research Council, Dhaka, 2005.

[20] F. T. Bingham, "Chemical Soil Tests for Available Phosphorus," Soil Science, Vol. 94, No. 2, 1962, pp. 87-95. doi:10.1097/00010694-196208000-00005

[21] SRDI, "Report of Land and Soil Resource Use, Hathazari Upazilla, Chittagong District," Upazilla Report Series-29, 2008.

[22] R. R. Simard, T. S. Tran and J. Zizka, "Strontium Chloride-Citric Acid Extraction Evaluated as a Soil Testing Procedure for Phosphorus," Soil Science Society of American Journal, Vol. 55, 1991, pp. 414-421.

[23] J. T. Sims, "Comparison of Mehlich-1 and Mehlich-3 Extractants for $\mathrm{P}, \mathrm{K}, \mathrm{Ca}, \mathrm{Mg}, \mathrm{Mn}, \mathrm{Cu}$, and $\mathrm{Zn}$ in Atlantic Coastal Plain Soils," Communications in Soil Science and Plant Analysis, Vol. 20, No. 17-18, 1989, pp. 1707-1726. doi:10.1080/00103628909368178

[24] Council for Agricultural Science and Technology, "Relevance of Soil Testing to Agriculture and the Environment," Issue Paper No. 15, CAST, Ames, IA, 2000, pp. $1-12$.

[25] M. Zhang, R. Wright, D. Heaney and D. Vanderwel, "Comparison of Different Phosphorus Extraction and Determination Methods Using Manured Soils," Canadian Journal of Soil Science, Vol. 84, 2004, pp. 469-475. doi: $10.4141 / \mathrm{S} 02-023$

[26] J. C. Fardeau, C. Morel and R. Boniface, "Why the Olsen Method Should Be Used to Estimate Available SoilPhosphorus (Fr.)," Agronomie, Vol. 8, No. 7, 1988, pp. 577-584. doi:10.1051/agro:19880702

[27] J. Archer, "Crop Nutrition and Fertiliser Use," Farming Press Ltd., Ipswich, 1988, pp. 57-64.

[28] S. C. Chang and S. R. Juo, "Available Phosphorus in Relation to Forms of Phosphates in Soils," Soil Science, Vol. 95, No. 7, 1963, pp. 91-97. doi:10.1097/00010694-196302000-00001
[29] P. F. Pratt and M. J. Garber, "Correlations of Phosphorus Availability by Chemical Tests with Inorganic Phosphorus Fractions," Proceedings of the Soil Science Society of America, Vol. 28, 1964, p. 23. doi:10.2136/sssaj1964.03615995002800010020x

[30] C. A. Black, "Phosphate Fixation by Kaolinite and Other Clays as Affected by $\mathrm{pH}$, Phosphate Concentration, and Time of Contact," Proceedings of the Soil Science Society of America, Vol. 7, 1942, p. 123. doi:10.2136/sssaj1943.036159950007000C0019x

[31] K. Anam, S. M. I. Huq and S. Enayetullah, "Efficiency of Extraction Methods Based on Availability Uptake Relationship of the Nutrients with Reference to Paddy in Some Soils of Bangladesh, II. Phosphorus and Potassium," Journal of the Asiatic Society of Bangladesh, 1978, Vol. 3, No. 2, pp. 19-26.

[32] K. Anam, D. Alam and S. M. I. Huq, "Choice of Extraction Methods in Assessing Available Nutrients," Bangladesh Journal of Soil Science, Vol. 17, 1981, pp. 66-76.

[33] K. Anam, D. Alam, S. Rahman and S. M. I. Huq, "Evaluation of the Suitability of the Methods for Assessment of Nutrients of Datmara Soils with Respect to Rubber Plant," Dhaka University Studies (B), 1982, Vol. 30, No. 2, pp. 181-189.

[34] G. K. M. Rahman, M. Jahiruddin, M. I. Ali, M. S. Hoque and M. Q. Hoque, "Effect of Soil Properties on the Extractions of Phosphorus and Its Critical Limit for Rice," Journal of the Indian Society of Soil Science, Vol. 43, 1995, pp. 452-456.

[35] J. T. Sims, "Soil Test Phosphorus: Mehlich-3 P," In: G. M. Pierzynski, Ed., Methods of Phosphorus Analysis for Soils, Sediments, Residuals and Waters, Southern Cooperative Series Bull, No. 396, Kansas State University, Manhttan, 2000, pp. 17-19.

[36] J. T. Sims, "Soil Test Phosphorus: Olsen P," In: G. M. Pierzynski, Ed., Methods of Phosphorus Analysis for Soils, Sediments, Residuals and Waters, Southern Cooperative Series Bull. No. 396, Kansas State University, Manhttan, 2000, pp. 20-21

[37] T. S. Tran, M. J. Guilbeault and P. Audesse, "Evaluation of Mehlich 3 Extractant to Estimate the Available P in Quebec Soils," Communications in Soil Science and Plant Analysis, Vol. 21, No. 1-2, 1990, pp. 1-28. doi: $10.1080 / 00103629009368212$

[38] J. C. R. Holford and G. J. Crocker, "Efficacy of Various Soil Phosphate Tests for Predicting Phosphate Responsiveness and Requirements of Clover Pastures on Acidic Tableland Soil," Soil Research, Vol. 26, No. 3, 1988, pp. 479-488. doi:10.1071/SR9880479

[39] J. W. Fitts, "Soil Tests Compared with Field, Greenhouse and Laboratory Results," Technical Bulletin No. 121, 1956.

[40] E. J. Kamprath and M. E. Watson, "Conventional Soil and Tissue Tests for Assessing the Phosphorus Status of Soil," The Role of Phosphorus in Agriculture, ASACSSA-SSSA, Madison, 1980, pp. 433-469.

[41] M. H. Rahman, M. Q. Haque and M. I. Ali, "Effect of Phosphorus on Dry Matter Production, Uptake and Its Critical Limit for Mungbean Indifferent Soils of Bangla- 
desh Using P as Traces," Bangladesh Journal of Soil Science, Vol. 26, 2000, pp. 59-95.

[42] I. Haque and C. Lahai, "Assessment of Soil Analytical Methods for Available Phosphorus in Some Sierra Leone Soils," Ghana Journal of Agricultural Science, Vol. 10,
1977, pp. 199-204.

[43] T. T. Ngoc and C. V. Phicaung, "Soil Phosphorus Availability Tests for Irrigated Lowland Rice in Cantho, Vietnam," Omonrice, Vol. 12, 2004, pp. 58-68. 